\title{
The "Interior Tradition" in American History: A Review Essay
}

\author{
JON LAUCK
}

Beyond the Frontier: The Midwestern Voice in American Historical Writing, by David S. Brown. Chicago: University of Chicago Press, 2009. xxvii, 227 pp. Illustrations, notes, bibliography, index. \$32.50 cloth.

New England has its Brahmins and patricians. The South has its Bourbons and romantic agrarians. New York City and Columbia University have their émigré Jewish intellectuals. All of these are familiar voices in the history profession and in American letters generally. Less well known at the moment, although once quite prominent, are some distant voices from the American Midwest, historians who shaped an emerging scholarly field.

After the Civil War, when historians were organizing themselves into a profession, the midwestern sectional identity blossomed. Victorious in war, blessed with rivers and fertile fields, increasingly industrial, and the inheritor of a virtuous rural republicanism, the Midwest flourished. Chicago became a center of commerce, Madison developed a new model of higher learning, and midwestern presidents ran the country. "The great interior," Lincoln said, had become the "great body of the republic" $^{\prime \prime}(4)$.

Historians from the Midwest, David Brown explains in his splendid new book, reflected the rhythms of their section and forged an "interior tradition" in American historical writing (190). Compared to aristocratic New England and the hierarchi-

THE ANNALS OF IOWA 69 (Winter 2010). (C) The State Historical Society of Iowa, 2010. 
cal and racially polarized South, the Midwest was more democratic and egalitarian, more attuned to agrarian populism, and less enthused about the exertion of federal power and the launching of foreign adventures. In the Midwest, the old "Anglo/rural folkways" persisted as they weakened in the East (xv). While the states of the Midwest each had its own unique elements, they "shared a territorial past and a sense of regional identity outside of eastern cosmopolitanism and southern exclusivity" (9).

From the late nineteenth century until the 1930s, the Midwest produced some of the nation's most prominent historians. Frederick Jackson Turner was a ninth-generation American descended from the Puritan founders, the son of a Wisconsin newspaperman and GOP activist, a devotee of fishing, camping, and hiking, a natural public speaker, and a witness to the passing of the frontier. In a great break with eastern historians, who saw midwestern culture and institutions as derivative and largely ignored what happened beyond the Hudson River, Turner famously argued that midwestern settlers perfected democratic practices on the frontier and begat a tradition of historical writing about and from the Midwest.

Charles Beard, a product of an Indiana farm, respected Turner but thought that his vision was too sentimental and that it failed to account for economic conflict. In addition to placing class at the center of American history, Beard lashed out at the wealthy internationalists in the East who, he thought, would endanger liberty at home by fighting wars abroad. As the nation's foreign commitments deepened and the "American Century" dawned, Beard and other politically active isolationists led what Brown calls a "midwestern resistance" to internationalism (51).

The attacks on Beard by eastern historians highlighted a growing schism within the profession between an "older progressivism and a budding postwar liberalism" (78). Eastern liberals rejected Beard's and his supporters' isolationism and their praise of midwestern agrarian movements. Richard Hofstadter, for one, famously branded the Populists as anti-Semitic provincials suffering from "status anxiety" in a new urban and cosmopolitan age. Eastern liberals also saw the rural Midwest as the home of McCarthyism, "ignorant biblical literalists, rednecks, 
and crypto anti-Semites," fascist and authoritarian undercurrents, and the generally darker aspects of democratic life (82).

Some midwesterners pushed back against the eastern liberals. Merle Curti, Turner's last doctoral student and a product of rural Nebraska, made his case by publishing The Making of an American Community in 1959. Curti, who was by then Frederick Jackson Turner Professor of History at the University of Wisconsin, examined the settlement of Trempealeau County, Wisconsin, and found much to vindicate Turner's views on the workings of frontier democracy. More generally, Curti criticized the elitism and "intellectual segregation" (88) embraced by Hofstadter and others and promoted a scholarly connection to the public and the taxpayers who supported state universities. Curti quoted Emerson: "March without the people, and you march into the night" (88).

Despite the efforts of Curti and others, the eastern liberals began to dominate the profession by mid-century. As Brown notes, the New Deal/internationalist/cosmopolitan historical perspective grew and old midwestern historians became "political and intellectual refugees in their own country" (100). What Wisconsin historian William Best Hesseltine called the "Harvard-Columbia axis" had, for the moment, prevailed.

But fragments of the old school of thought would persist. Wisconsin, where midwestern progressivism lived on, attracted a large number of younger Jewish scholars from the East who sought out a more radical tradition. The history of dissent at Wisconsin made it an "inviting location for Jewish students eager to join in a kind of heartland radicalism" (113). Several of those young Jewish scholars at Wisconsin founded Studies on the Left in 1959. "Studies was pretty much Jewish," recalled its only "Gentile editor," but it made common cause with other Wisconsin students critical of American foreign policy such as Walter LaFeber (from Indiana), Lloyd Gardner (from Ohio), and Thomas McCormick (also from Ohio), who were all affiliated with the Wisconsin School of Diplomatic History (114). While they shared an opposition to liberalism, they proceeded from differing perspectives. LaFeber, for example, was the son of an Indiana grocer who hated the New Deal's taxes and bureaucracy and thought FDR "lied us into the war" (115). 
The opposition to American foreign policy at Wisconsin came to be embodied in William Appleman Williams. Williams, who was born in Atlantic, Iowa, and had absorbed the politics of the Grange and the Farmers' Alliance as a child, joined the Wisconsin faculty in 1957. Because of his rural roots, Williams did not see the Populists as either proto-fascists or proto-revolutionaries, as some easterners did. He correctly saw the Populists as dedicated "very intelligently and thoroughly to the JeffersonianJacksonian set of ideas, policies, and tradition" (135).

Williams's best-known commentary related to foreign affairs and followed Beard, but his timing proved more fortuitous. In contrast to Beard's questionable critique of the "Good War" against Nazi Germany and imperial Japan, Williams's books attacking the economic roots of American foreign policy attracted attention just as the Cold War consensus was withering. As a confessed Marxist, as someone who blamed American actions for Soviet expansionism after World War II, and as a critic of American "imperialism," Williams's scholarship was absorbed by the antiwar activists of the New Left. The president of Wisconsin later said that through his published works and personal statements Williams "incited" students to demonstrate and protest and became a "great hero of radical historians" $(134,146)$.

Due in part, surely, to his roots in small-town Iowa, Williams broke with student activists over their extreme radicalism and fled to Oregon State University. Walter LaFeber recalled that Williams "felt strongly that any type of protest that threatened violence, especially in a university setting, was unacceptable" (145). Still, Brown argues, in our current age of foreign entanglements, Williams's worldview remains "compelling." Brown believes that Williams's work "carried the voice of Atlantic [Iowa] and of a thousand other interior hamlets bereft of a champion since Beard" (146). Williams's critique also carries on in the academy. Brown notes, for example, its link to the "new western history" and works such as Patricia Nelson Limerick's The Legacy of Conquest (1987), which shaped a generation of historical writing about the American West. Limerick embraces Williams as "my predecessor" and views the American westward movement in the category of "colonialism and imperialism": "A recognition of the centrality of Empire, with a capital e, now drives 
and energizes my field" (140). The darker portrayal of the history of the American West advanced by Limerick and other "new western historians" is generally considered a rebuff to the rosier interpretation offered by Turner.

Williams's break with the New Left over its violent tactics underscores the frustration with radicalism that animated the work of Brown's final subject of study, the brilliant and hard-tocategorize Christopher Lasch. While not born to a farm like many midwestern historians, Lasch maintained strong midwestern credentials. His maternal grandfather was a Nebraska legislator, and his mother, who held a Ph.D. from Bryn Mawr, taught philosophy and psychology at the University of Nebraska, and roomed with Willa Cather's sister. She married her best student, Robert Lasch, who became a reporter for the Omaha World-Herald and later the Chicago Sun-Times and the St. Louis Post-Dispatch. Christopher was born in Omaha in 1932.

Lasch's first books explored how American liberals reacted to World War I and the emergence of intellectuals as a social group. In his early writings, Lasch began to question liberals' elitism and to develop a powerful critique of liberalism's undemocratic tendencies. Lasch attacked the experts and bureaucrats who ran the burgeoning federal state and managed foreign wars and condemned intellectuals for cozying up to power and distancing themselves from the masses. When Hofstadter kidded Lasch about his jabs at the eastern intelligentsia, Lasch, then at the University of Iowa, told Hofstadter that he did not intend to cause friction "between the New York intellectuals and the intellectuals of Dubuque" (155). But Lasch certainly did mean to expose liberals' pretentiousness and abuses of power. Lasch, Brown explains, was targeting "years of aggressive, tradition-upending social engineering on the part of high liberalism" (155). Liberalism, Lasch argued, had broken from the "dominant values of American culture" (155).

Lasch thought that liberals had abetted the student rebellion and cultural radicalism of the 1960s. He turned down a full professorship at Wisconsin in favor of a post at Northwestern because of his disapproval of the "loony Left at Madison" and because Northwestern had not attracted the Maoists, Guevaristas, and Stalinists who found a home in Madison (158). Instead 
of attaching itself to Che and Chinese communism, the American left, Lasch thought, could have grounded itself in homegrown traditions of reform and resistance. Precedents for Lasch's selfprofessed goals of "decentralization, local control, and a generally anti-bureaucratic outlook" could be found in the Midwest (159). The family, church, farm, and traditional social codes were the best defenses against the disintegrating effects of individualism, the market, and modern culture, Lasch argued, but they were cast aside by liberals and radicals as evidence of a "proto-fascist mentality" (168). In 1979, the year Lasch published his famous work The Culture of Narcissism, he wrote in a letter that the "Left has nothing to say to the people who are worried about crime, discontinuity, disruption of the family, collapse of authority, bureaucracy, and the gospel of hedonistic self-indulgence purveyed by the mass media" (168).

Brown intelligently connects Lasch's critique, grounded in his own experience in the Midwest, to the works of Turner, Beard, and Williams and offers a wonderfully rendered portrait of a midwestern mindset. It is a bracing and well-executed encore to his first book on the intellectual development and output of Richard Hofstadter. Brown chose his subjects based on their impact on the profession and their proven ability to shape historical debate. He had to draw the line somewhere, but his discussion of midwestern historians such as Merle Curti, John Hicks, and Howard K. Beale leaves one wishing that they could have been given their own chapters.

Brown discusses several historians who will be recognizable to practicing historians, but a deeper examination of a lesserknown second tier of midwestern historians would also have been revealing. Clarence W. Alvord of the University of Illinois, Benjamin F. Shambaugh of the University of Iowa, Elwyn B. Robinson of the University of North Dakota, Herbert S. Schell of the University of South Dakota, Theodore C. Blegen of the University of Minnesota, and James C. Malin of the University of Kansas come to mind. Alvord was a strong proponent of maintaining the regional distinctiveness of the Mississippi Valley Historical Association (MVHA) and fought the cooptation efforts of the American Historical Association, which, he argued, was too focused on the East. Shambaugh, another champion of the 
MVHA, also placed great importance on speaking to a public audience, popularizing history, generating a "commonwealth" history by studying subjects such as constitutional development, and generally recognizing "history's utilitarian possibilities." Alvord, Shambaugh, and others could have added another layer of texture to Brown's exploration of the midwestern mindset. For additional background, Brown could have linked the efforts of these midwestern historians to the growth of midwestern regionalism more generally in the early decades of the twentieth century. ${ }^{2}$

In addition to explicating the grand themes articulated by the midwestern historians discussed in his book, Brown offers a stark and dismaying account of the petty, personal, and political side of the historical profession. He captures the thoroughgoing snobbishness of eastern historians toward what they saw as western provincials and the resulting rebellion against eastern dominance in the West. Just as Turner was beginning his effort to put the West on the historical map, one Brown University historian - in a sign of what Turner was up against - simply pronounced that "Western history is stupid" (25).

Brown also reports on the profession's squabbling and incessant internal feuds: Turner's exile of his student Orin Libby to North Dakota (55); Curti fighting with Samuel Eliot Morrison and therefore losing his chance to move to Harvard (200); Oscar Handlin's comparison of Williams's The Contours of American History to the "literary strivings of unskilled freshmen," and John Higham's subsequent criticism of Handlin for "bullying" (143); the political pressures surrounding the publication of a festschrift to Beard that caused Yale University Press and Knopf to abandon the project (68); professors warning graduate students to hide their research from hostile scholars and their students (132); and the attempts to topple Clara Paine, whose "western matriarchy"

1. John R. Wunder, "The Founding Years of the OAH," OAH Newsletter 34 (November 2006); Rebecca Conard, Benjamin Shambaugh and the Intellectual Foundations of Public History (Iowa City, 2002), 11. For more on the formative growth of the Mississippi Valley Historical Association, see Ian Tyrrell, "Public at the Creation: Place, Memory, and Historical Practice in the Mississippi Valley Historical Association, 1907-1950," Journal of American History 94 (2007), 19-46.

2. See Robert L. Dorman, Revolt of the Provinces: The Regionalist Movement in America, 1920-1945 (Chapel Hill, NC, 1993). 
controlled the old MVHA from Lincoln, Nebraska (92). Brown covers all these and other internal machinations of the profession. He even digs up the old historians' salaries. He also conjures moments of genuine comedy, such as the time, bizarre in retrospect, when Allan Nevins tried to convince Christopher Lasch to write his dissertation about the logging business of the Pacific Northwest.

Brown's trip through the correspondence of dead historians is a reminder of the profession's continuing shortcomings. Personal and political conflicts still crowd out open and honest debate. Younger scholars fear angering older colleagues who can influence their careers, and political correctness inhibits open inquiry. Some historians retreat to the bunker and avoid the give-and-take of the marketplace of ideas and write on topics so narrow and obscure that they are difficult for their peers to analyze and therefore make only minor contributions to our store of knowledge. Patricia Nelson Limerick has admitted her frustration with the complete lack of response to the American Historical Association's attempt to organize debates between prominent scholars on major topics. ${ }^{3}$ There are obvious exceptions to this state of affairs, but there is much to be honored in the midwestern historians' broad-gauged attempts to address the grand themes of democracy, the frontier, capitalism, and the nation's engagement with the world.

Throughout the book, Brown also records evidence of the profession's once widespread anti-Semitism and recounts how university presidents would monitor the number of Jewish professors on campus and, if they allowed Jewish professors at all, determine if they were too Jewish. Brown recounts Turner's "soft anti-Semitism" and his doubts about the effect of eastern and southern Europeans on his Anglo-American rural Midwest, but also recognizes that Turner was far from a fanatic (48). One of Turner's Jewish and socialist students recognized his democratic egalitarianism and said that Turner embraced a "nationalism with the 'welcome sign' out to all who were capable of being infected with his own inspiring enthusiasm for America" (48).

3. Patricia Nelson Limerick, Something in the Soil: Legacies and Reckonings in the New West (New York, 2001), 337-38. See also Richard White, "What Are We Afraid Of?" OAH Newsletter 34 (August 2006). 
Long after Turner, Brown notes, Williams remained skeptical of the "aggressiveness" of Jewish student radicals in the 1960s and, as one Wisconsin professor recalled, "was always looking for the blond and blue-eyed Iowa Socialist, one who shared his own roots, which lay deep in the Iowa prairie" (114).

All the infighting and personal attacks and the discrimination against certain groups recounted by Brown are a reminder of the multiple and contested points of view on the past, what Beard described, rather unfortunately, as "relativism." Beard was not endorsing the fashionable postmodern view that the past is hopelessly confused and meaningless and that facts are impossible to determine, but simply trying to prevent the midwestern point of view from being delegitimized and marginalized by the increasingly prominent eastern liberals. Beard, Brown says, feared that the "prevailing conception of normative truth would be both defined and wielded by a rising eastern liberalism" (63). Beard wanted to ensure that midwestern voices would still be taken seriously and not drowned out by the easterners.

Brown's account of Beard's attempt to preserve a midwestern perspective, along with the massive amount of personal correspondence and reflections he uses to distill the midwesterners' vision of history, makes his book first-class intellectual history. It belongs on the shelf next to classics such as Peter Novick's That Noble Dream and John Higham's History. ${ }^{4}$ Brown's treatment also benefits from his own midwestern roots. He grew up in West Milton, Ohio (population 4,500), home to oldtime farm families and main street businesses, and his family tilled the soil and milked cows. Brown's education also took him to three corners of Ohio, where he earned degrees from universities in Dayton, Akron, and Toledo.

Perhaps Brown's lived experience in the Midwest also helped him capture a more nuanced aspect of the midwestern historical persuasion, one that can escape notice by simply studying the texts of midwestern historians. One Wisconsin graduate student, Richard Schickel, who went on to become Time magazine's film critic, captured the temperament. He recalled that the small-town

4. Peter Novick, That Noble Dream: The "Objectivity Question" and the American Historical Profession (New York, 1988); John Higham, History: Professional Scholarship in America (Baltimore, 1983). 
boys from the Midwest maintained a steady calm, "a sense that most crises were not terminal, that the seasons, the world, would roll on in their accustomed ways." Graduate students from New York, however, shaped by the "nervous energy" of the metropolis and, in many cases, by their "Jewish leftist backgrounds" and the shadow of the Holocaust, were far from sanguine. Schickel noted that while the "WASPs had a healthy sense of security about history's reliable course, the Jews had an equally healthy sense of its unreliability" (112). ${ }^{5}$

Brown's diligent and faithful effort to capture the midwestern influence on the historians he respectfully analyzes should not be taken to mean that they were right. Beard's interpretation of the writing of the federal Constitution, for example, has been convincingly debunked, and Williams's conspiratorial foreign policy theories are eccentric. Hofstadter and others successfully argued that there was much more consensus in American politics than Beard and his followers could brook.

With the exception of Turner and the partial exception of Lasch, Brown's book might better be seen as an account of a prominent midwestern tradition of leftist historical writing. It reveals, in other words, $a$ midwestern historical tradition, not the midwestern historical tradition. Brown's extensive focus on Wisconsin, for example, leaves the reader seeking a more complete explanation of the sentiments at other midwestern universities, where "uptight Midwest kids," in the words of one Jewish editor of Studies on the Left, were studying history (113). Another, more conservative, midwestern perspective was at work at the "football and dairy colleges" (86). By focusing on the University of Wisconsin, Brown misses a less radical version of the midwestern persuasion. His masterful, detailed examination of the happenings at Wisconsin leaves readers wondering about what was happening at the University of Iowa and Indiana University and all the active state historical societies in the Midwest where Wisconsin radicalism was less attractive but where genuinely midwestern voices were articulated.

5. On the uniqueness of the midwestern temperament, see R. Douglas Hurt, "Midwestern Distinctiveness," in Andrew R. L. Cayton and Susan E. Gray, eds., The Identity of the American Midwest: Essays on Regional History (Bloomington, IN, 2001), 160-79. 
There are, it should be emphasized, less radical elements of the midwestern persuasion. Many midwesterners simultaneously embraced the rural republicanism of the Midwest and opposed eastern cultural and bureaucratic dominance but were also more accommodating of economic growth and supportive of America's military might than Brown's subjects. Prominent midwestern isolationists such as Senators Arthur Vandenberg and Karl Mundt, for example, abandoned isolationism in favor of international commitments that they believed would protect the American republic and did so without embracing imperialism.

Brown could also have justifiably spent more time considering the un-midwesterness of the radicalism that Wisconsin helped spawn. Lasch accepted a position at Northwestern instead of Wisconsin and Williams fled Wisconsin, after all, because its radicalism offended their midwestern sensibilities. That Lasch's early radicalism ended in his excoriation of the "loony Left" at Wisconsin and that Williams went from "inciting" students at Wisconsin to fleeing the scene in frustration surely deserve greater weight in the course of contemplating Wisconsin's legacy. Even Hofstadter, the dean of the eastern intellectuals, turned on the Left in the 1960s, as Brown explained in his first book. Brown notes that the frustration of midwestern historians with the 1960s Left stemmed from their heritage, but one is left hoping for a more complete explanation of the breach and evidence of their contrition for what they helped start and, for a time, abetted.

The dissenters and radicals of Wisconsin were once the exception, but that is no longer the case. One professor commented in 1960 that the intellectuals affiliated with Studies on the Left would be the "college and university professors of the next generation" and that "when they come to power in our universities - and their coming to power is only a matter of time will have an important bearing on the intellectual life of our country" (116). This "coming to power" has come to pass, as has been widely noted in the popular press and in what Brown describes as "backlash books" (116). The prevalence of the Left in the present-day historical profession is made that much more remarkable by Brown's review of the one-time attacks by midwestern progressives on the conservatism of eastern universi- 
ties. It is a long time ago indeed when Samuel Eliot Morrison successfully belittled and marginalized historians for questioning the nation's exercise of military power, and the trustees of Columbia University warned professors against teachings "likely to inculcate disrespect for American institutions" (58). The midwesterners Brown examines were present at the creation of the activist university Left and anticipated the later backlash against it and the threat it posed to the preservation of the democratic ideals and small-town, rural culture they held dear.

Finally, Brown also underestimates the links between a midwestern mindset and the recent age of Reagan. Brown believes that contemporary conservatism directly conflicts with the midwestern tradition he highlights because it embraces and celebrates "economic growth and war-making capability" (191). But it also opposes federal bureaucratic controls and the power wielded by eastern liberals and promotes small-town culture and folkways in a fashion reminiscent of Turner and Curti. Brown notes that what united his midwestern historians was, in essence, their "concerns about the centrality of power and politics in eastern hands," concerns that are fully compatible with the philosophy of political conservatives (191). Ronald Reagan, after all, was from small-town Illinois and ultimately broke with the New Dealers over their statist tendencies. By extending his analysis more broadly beyond Wisconsin, Brown would have detected this other midwestern tradition.

These are, perhaps, topics for Brown's next book. In Beyond the Frontier, Brown has provided historians with a powerful reminder of a once resonant and influential midwestern tradition of historical writing. While a shadow of its former self, midwestern history can boast of recent incisive works by Andrew Cayton, Nicole Etcheson, Jon Gjerde, and Susan Gray. And, as Brown notes, William Cronon, who has returned home to Wisconsin to write the Midwest's environmental history, and Thomas Frank, the popular polemicist from Kansas, both ground their work in a midwestern tradition. Perhaps with Brown's reminder, more historians will revisit the Midwest's history and its lively tradition of historical scholarship. 